\title{
Control of red fox (Vulpes vulpes) fertility with cabergoline: dose response and timing of intervention
}

\author{
C. A. Marks ${ }^{1}$, L. Jalkanen², R. Savolainen ${ }^{2}$ and R. V. Short ${ }^{3}$ \\ ${ }^{1}$ Vertebrate Pest Research Department, Victorian Institute of Animal Science, PO Box 48, \\ Frankston, Victoria 3199, Australia; ${ }^{2}$ Department of Applied Zoology and Veterinary \\ Medicine, University of Kuopio, Kuopio, Finland; and ${ }^{3}$ Department of Obstetrics and \\ Gynaecology, University of Melbourne, Parkville, Victoria 3052, Australia
}

\begin{abstract}
Cabergoline, a potent dopamine agonist and inhibitor of prolactin secretion, was investigated as a potential fertility control agent in the red fox (Vulpes vulpes). Sixty silver fox vixens were selected randomly and artificially inseminated. Cabergoline was fed to groups of 12 vixens in a minced beef ration either as a single dose of 25,50 or $100 \mu \mathrm{g} \mathrm{kg}^{-1}$, or a dose of $50 \mu \mathrm{g} \mathrm{kg}^{-1}$ that was repeated 2 days later $\left(2 \times 50 \mu \mathrm{g} \mathrm{kg}^{-1}\right)$. Four foxes from each group of 12 were given cabergoline at day 28 , day 35 or day 48 after artificial insemination, and a control group of four foxes was used as a comparison for each dose day. In a separate trial, two groups of five foxes were selected randomly from the farm population and fed $100 \mu \mathrm{g} \mathrm{kg}^{-1}$ of either cabergoline or a placebo each day from day 42 to day 46 of pregnancy. Foxes that received single doses of cabergoline of $100 \mu \mathrm{gg}^{-1}$ or $2 \times 50 \mu \mathrm{gg}^{-1}$ aborted at day 28 , but the same doses did not result in abortions when administered
\end{abstract}

\section{Introduction}

Predation of wildlife by the introduced red fox (Vulpes vulpes) is considered a major threat to the conservation of a range of terrestrial wildlife species in Australia (Mansergh and Marks, 1993; Saunders et al., 1995; Anon, 1996). Currently, management of fox populations is limited to the use of poison baiting with 1080 (sodium fluoroacetate), shooting, trapping and killing, exclusion fencing and den fumigation. Concerns over the potential impacts of 1080 baiting on domestic and wildlife species such as quolls (Dasyurus maculatus) (Soderquist and Serena, 1993; Belcher, 1998), although not confirmed in some field studies (King, 1989; Mcllroy, 1993), currently limits the broad-scale use of baiting in some habitats. The conservation of some Victorian wildlife populations, including eastern barred-bandicoots (Perameles gunni), little penguins (Eudyptula minor) and mountain pygmy possums (Burramys parvus), is compromised by foxes that inhabit adjacent urban developments that are not easily managed with

Email: camarks@attglobal.net on days 35 and 48. Although lactation was not terminated in groups that received a single or double dose of cabergoline, increased post-natal cub mortality was associated with cabergoline administration. Growth of cubs between 4 and 8 weeks of age was not inhibited in vixens that received cabergoline. Doses of $100 \mu \mathrm{g}$ cabergoline $\mathrm{g}^{-1}$ administered each day from day 42 to day 46 resulted in abortions and terminated lactation. The capacity of single doses of cabergoline to cause abortions in the red fox during mid- rather than late pregnancy is contrary to reported observations for the domestic dog. This finding indicates that luteotrophic support of the corpus luteum by prolactin may be more important at mid-pregnancy in the red fox. The results of this study support previous field observations that cabergoline delivered in bait affects the reproductive success of vixens and may be a practical adjunct to the lethal control of wild red foxes in Australia. current methods (Mansergh and Marks, 1993; Marks and Short, 1996; Marks et al., 1996). Control of foxes by manipulating fertility may prevent population increase after lethal control (Bomford, 1990; Bomford and O'Brien, 1992), as well as the dispersal of foxes from urban habitats to rural areas containing susceptible wildlife species (Marks and Short, 1996; Marks et al., 1996).

Methods to reduce prolactin secretion induce abortions in domestic dogs (Canis familiaris) when administered after week 6 of pregnancy (Conley and Evans, 1984; Post et al., 1988; Concannon et al., 1989; Jöchle et al., 1989; Olson et al., 1989). In red foxes, inhibition of prolactin secretion is thought to cause luteal regression and abortion during the second half of pregnancy (Hartley et al., 1994). Cabergoline (1-[(6allylergolin-8 $\beta-y 1)$ carbonyl]-1-[3-(dimethylamino)propyl]-3 ethylurea) is a dopamine agonist with an extremely high affinity for the dopamine receptor sites on the anterior pituitary lactotrophs (Benedetti et al., 1990), and its capacity to inhibit prolactin secretion is more potent than that of bromocriptine (Pontiroli et al., 1987; Dall'Ara et al., 1988; Post et al., 1988; Caballero-Gordo et al., 1991; Rolland et al., 1991; Ferraro et al., 1992). Cabergoline 
administration has been demonstrated to terminate or reduce lactation in the domestic dog (Jöchle et al., 1989). The placement of baits containing cabergoline in proximity to natal dens during the breeding season significantly reduced the reproductive success of vixens in an urban and rural field site (Marks and Short, 1996; Marks et al., 1996) although it was impossible to conclude whether this was due to the termination of lactation, abortion or a combination of both. Furthermore, the timing and dose of cabergoline that lead to abortion in red foxes is unknown. The aim of the present study was to determine the dose and timing of cabergoline administration required to reduce the reproductive success of the red fox.

\section{Materials and Methods}

\section{Study site and captive animals}

Experiments were conducted at the Juankoski research farm at the Department of Applied Zoology and Veterinary Medicine, University of Kuopio $\left(62^{\circ} 40^{\prime} \mathrm{N} 28^{\circ} 30^{\prime} \mathrm{E}\right)$, Finland. All procedures were approved by the Victorian Institute of Animal Science Animal Ethics Committee as protocol number 1810, and by the University of Kuopio Animal Ethics Committee. Foxes were of the silver coat phenotype of the red fox born at the farm during the previous breeding season. One-year-old vixens were selected to ensure uniform breeding success. Each vixen was housed in one of two facilities containing 48 steel mesh pens $(1.1 \mathrm{~m} \times 1.1 \mathrm{~m} \times 0.9 \mathrm{~m})$ arranged in two parallel rows with a galvanized steel roof that provided shelter from rain and snow. Each pen was fitted with insulated wooden breeding boxes with an internal chamber of $0.4 \mathrm{~m} \times 0.4 \mathrm{~m}$ $\times 0.4 \mathrm{~m}$ (Mononen et al., 1995, 1996). Water was provided ad libitium via an automatic watering system connected to the front of each cage. Food was provided each day and consisted of a meat slurry that was injected into a feeding hopper on the front of the cage.

Table 1. Final sample size in each treatment group after removal of red fox (Vulpes vulpes) vixens in which no oestrus or placental scars had been detected or where animals had to be killed before whelping

\begin{tabular}{|c|c|c|c|c|c|}
\hline \multirow[b]{2}{*}{ Group } & \multirow{2}{*}{$\begin{array}{c}\text { Dose of } \\
\text { cabergoline } \\
\left(\mu \mathrm{kg}^{-1}\right)\end{array}$} & \multirow[b]{2}{*}{$n$} & \multicolumn{3}{|c|}{$\begin{array}{l}\text { Number of animals } \\
\text { treated on each } \\
\text { day of pregnancy }\end{array}$} \\
\hline & & & Day 28 & Day 35 & Day 42 \\
\hline \multirow[t]{3}{*}{1} & 25 & 10 & 3 & 4 & 3 \\
\hline & 50 & 11 & 4 & 4 & 3 \\
\hline & 100 & 11 & 4 & 3 & 4 \\
\hline 2 & $50 \times 2$ & 10 & 4 & 4 & 2 \\
\hline 3 & Placebo $\times 2$ & 9 & 3 & 3 & 3 \\
\hline Total & & 51 & 18 & 18 & 15 \\
\hline
\end{tabular}

Oestrus was detected by monitoring the electrical resistance of the vaginal tract using the probe method described by Møller et al. (1984a). After detection of oestrus, vixens were artificially inseminated using freshly collected diluted semen as described by Fougner et al. (1973) and Fougner (1989). The duration of gestation in wild red foxes is 52-53 days (Ryan, 1976; Lloyd, 1981; Coman, 1983) and vixens usually whelped more than four cubs, although litter sizes and mortality rates after birth vary with different geographical locations (Voigt, 1987). In Finland, a national mean of 3.85 viable cubs per litter was recorded from 2886 1-year-old vixens (Smeds, 1991). Between 1995 and 1998 at the Juankoski farm, a mean of $3.18(\mathrm{SD}=1.47)$ and $4.47(\mathrm{SD}=1.70)$ cubs per litter survived 2 weeks after whelping. The duration of gestation in vixens during the same period was $52.8(\mathrm{SD}=1.77)$ and 53.58 $(\mathrm{SD}=1.48)$ days, respectively (Jalkanen, 1992).

\section{General procedures}

Sixty vixens from the general farm population were allocated randomly to either a treatment $(n=48)$ or a control group ( $n=12$ ) (Table 1 ). Typically, oestrus was detected at the farm from mid-February to April and artificial insemination was performed thereafter. Foxes were weighed on digital scales (GWB, Mettler PE 12) at the time of artificial insemination before the animal was returned to its cage. No handling of foxes was permitted after this time to reduce the possibility of stress-induced abortion (Hartley et al., 1994). The weight of each vixen at the time of treatment was extrapolated from a profile of mean weight increases in vixens during pregnancy in the previous 2 years that had been kept in the same housing conditions and fed the same diet. This extrapolation resulted in an increase of 8, 10 and $15 \%$ over the weight recorded at artificial insemination for vixens treated at days 28, 35 and 48 , respectively.

Tablets consisting of $0.5 \mathrm{mg}$ cabergoline and $76 \mathrm{mg}$ lactose excipient (Dostinex, Pharmacia) were ground to a fine powder using a mortar and pestle to produce $30 \mathrm{mg}$ cabergoline from 60 tablets. Powdered cabergoline was apportioned in 25, 50 and $100 \mu \mathrm{g} \mathrm{kg}{ }^{-1}$ doses for each fox, and stored individually in air-tight containers in darkness at room temperature. A dose of $500 \mathrm{mg}$ lactose was apportioned for each control fox and stored under the same conditions as those for cabergoline.

Foxes were not fed in the $24 \mathrm{~h}$ before administration of either cabergoline or the placebo, but water was provided ad libitium. Cabergoline and placebo doses were fed to foxes in $50 \mathrm{~g}$ portions of minced beef. The powdered cabergoline and placebo were added to the food ration and mixed thoroughly. A sheet metal plate $(30 \mathrm{~cm} \times 10 \mathrm{~cm})$ was tied using wire to the base of the cage and the mincebeef portion was flattened against the surface of the plate to prevent the fox from moving it over the wire floor or into the breeding box. Before the start of the study, five adult male foxes were fed two doses of $100 \mu \mathrm{g}$ cabergoline $\mathrm{kg}^{-1}$ at $48 \mathrm{~h}$ 
intervals, using the described protocol. Observations of each male fox revealed that the meat and cabergoline were totally consumed on both occasions and there were no detectable losses. No vomiting or adverse effects were observed in the male foxes in the 2 days after ingestion. However, ingestion of the meat was confirmed routinely by observing foxes from a distance of about $5 \mathrm{~m}$ and any vomiting observed in a $2 \mathrm{~h}$ period thereafter was recorded.

Twelve foxes were allocated randomly to each treatment group: (i) group 1, a single dose of either 25, 50 and $100 \mu \mathrm{g}$ cabergoline $\mathrm{kg}^{-1}$; group 2, a single dose of $50 \mu \mathrm{g}$ cabergoline $\mathrm{kg}^{-1}$, which was repeated $48 \mathrm{~h}$ later $\left(2 \times 50 \mu \mathrm{g} \mathrm{kg}^{-1}\right)$; and (iii) group 3, a control group that received a placebo, which was repeated $48 \mathrm{~h}$ later. Four foxes were selected from each group at day 28 , day 35 or day 42 of pregnancy and given the appropriate treatment of cabergoline or a placebo (Table 1 ). In a separate trial, another ten 1 -year-old vixens were selected from the general farm population, of which five vixens received an oral dosage of $100 \mu \mathrm{g}$ cabergoline $\mathrm{kg}^{-1}$ each day from day 42 to day 46 of pregnancy and the other five vixens received a placebo during the same period.

Whelping boxes for carbergoline-treated and control foxes were inspected three times each week, and inspections commenced 4 weeks after artificial insemination to habituate the foxes to disturbance. Inspections continued even when an abortion was recorded. The whelping box was inspected for evidence of an abortus, blood, tissues or discharges. Whelping was detected by direct observation; however, during the period between visual inspections, the sound of recently born cubs was used to determine whether normal lactation and maternal care had started. If abnormal vocalization from cubs was recorded, an investigation through direct observation was carried out the next day.

Visual inspections of whelping boxes enabled a record of litter size and cub survival to be maintained. At week 4 after whelping, cubs were identified individually with subcutaneous micro-chip transponders and weighed each week for 5 weeks. Uterine and ovarian materials were collected via ovariohysterectomy between day 73 and day 108 from the day of artificial insemination. The number and presence or absence of uterine scars and corpora lutea were determined via gross examination (Allen, 1983; Lindstrom, 1986).

\section{Statistical analysis}

Logistic regression and probit analyses were performed to test for significant effects of log (dose) and log (timing) of cabergoline administration on abortions (Zar, 1984). The difference in the median number of cubs born to vixens treated with either cabergoline or the placebo from day 42 to day 46 of pregnancy was tested with the Mann-Whitney rank sum test. One-way ANOVA was performed to compare mean litter size at birth with weaning for each dose range, and Tukey's test was performed to test for significant differences between the means at $P<0.05$. Mean cub weight per litter and total litter weights for treatment and control groups at weeks 4, 5 and 6 after whelping were also compared using ANOVA. The growth rate of each cub was calculated by fitting a straight line to the cub weights recorded from week 4 to week 8 , and rates were then compared using ANOVA.

\section{Results}

\section{Necropsy and adjusted sample size}

No placental scars were detected in seven vixens that did not whelp, although between five and seven corpora lutea were visible in each case. Oestrus was not detected in one vixen that was to receive a dose of $2 \times 50 \mu \mathrm{g}$ cabergoline $\mathrm{kg}^{-1}$ at day 42, and artificial insemination was not performed. One vixen that was to receive a dose of $25 \mu \mathrm{g}$ cabergoline $\mathrm{kg}^{-1}$ at day 25 was killed 3 days after artificial insemination as a result of a limb injury. These nine animals were not considered in the assessment of doseresponse and the sample size for statistical analysis was adjusted accordingly (Table 1 ).

\section{Abortion and lactation}

Abortions were not observed in any of the control vixens, although they were observed in three of four vixens in both groups that received the $2 \times 50 \mu \mathrm{g} \mathrm{kg}^{-1}$ and $100 \mu \mathrm{g} \mathrm{kg}^{-1}$ doses of cabergoline at day 28 of pregnancy (Table 2). Emesis was observed in the single vixen treated with $100 \mu \mathrm{g}$ cabergoline $\mathrm{kg}^{-1}$ at day 28 that was not observed to abort and, therefore, it is likely that a full dose of cabergoline was not ingested. Notably, no abortions were observed at the same dose at day 35 and only one occurred in the group treated with $100 \mu$ g cabergoline $\mathrm{kg}^{-1}$ at day 42 (Table 2). Probit and logistic regression models indicated significant effects $(P<0.05)$ of dose and timing of cabergoline on the probability of abortion and little difference in the goodness of fit for either model. The probability of abortion increased with dose, but decreased when treatment occurred later in pregnancy. Lactation commenced in all vixens that whelped and had received a single or double dose of cabergoline, irrespective of cub survival. Copious milk could be expressed from the teats of all vixens that lost their litters, although comparative lactation performance between vixens treated with cabergoline and control animals could not be estimated.

Four of five vixens that received $100 \mu \mathrm{g}$ cabergoline $\mathrm{kg}^{-1}$ each day from day 42 to day 46 of pregnancy aborted their litters, whereas one vixen whelped five cubs that survived to weaning. One vixen in the control group failed to whelp, although no indication of an abortion was detected. Means of 0.8 (SD = 1.8) and 4.4 (SD = 1.9) cubs per litter were born in the cabergoline-treated group and the control group, respectively. The median number of cubs born per litter for each group was significantly different $(T=17 ; P<0.05)$. 
Table 2. Incidence of abortions in red foxes (Vulpes vulpes) in each treatment group

\begin{tabular}{|c|c|c|c|c|c|}
\hline \multirow[b]{2}{*}{ Group } & \multirow{2}{*}{$\begin{array}{c}\text { Dose of } \\
\text { cabergoline } \\
\left(\mu \mathrm{kg}^{-1}\right)\end{array}$} & \multirow[b]{2}{*}{$n$} & \multicolumn{3}{|c|}{$\begin{array}{l}\text { Number of abortions } \\
\text { in animals treated on } \\
\text { each day of pregnancy }\end{array}$} \\
\hline & & & Day 28 & Day 35 & Day 42 \\
\hline \multirow[t]{3}{*}{1} & 25 & 10 & $1 / 3$ & $1 / 4$ & $1 / 3$ \\
\hline & 50 & 11 & $1 / 4$ & $1 / 4$ & $0 / 3$ \\
\hline & 100 & 11 & $3 / 4$ & $0 / 3$ & $1 / 4$ \\
\hline 2 & $50 \times 2$ & 10 & $3 / 4$ & $0 / 4$ & $0 / 2$ \\
\hline 3 & Placebo $\times 2$ & 9 & $0 / 3$ & $0 / 3$ & $0 / 3$ \\
\hline Total & & 51 & & & \\
\hline
\end{tabular}

\section{Litter size, cub survival and growth rates}

There was no significant difference in the mean litter sizes of all vixens at day 2 that had been treated with either a placebo or any dose of cabergoline $\left(F_{3,27}=0.979\right)$. Cub mortality rates in the control group were 6,7 and $8 \%$ for days 28, 35 and 42, respectively. In the cabergoline-treated groups, litter loss after birth varied between 0 and 100\% (Table 3). Mean litter survival up to week 4 for all foxes treated with either 25,50,2 ×50 and $100 \mu$ g cabergoline $\mathrm{kg}^{-1}$ for combined dose times were significantly different $\left(F_{4,35}=3.423 ; P<0.05\right)$; the group that received $50 \mu \mathrm{g}$ cabergoline $\mathrm{kg}^{-1}$ had a lower mean survival rate than the group that received the placebo $(P<0.05)$ or $25 \mu \mathrm{g}$ cabergoline $\mathrm{kg}^{-1}(P<0.05)$ (Fig. 1). The value for mean cub survival for the group that received $2 \times 50 \mu$ g cabergoline $\mathrm{kg}^{-1}$ was lower than that for the group receiving the placebo, or 25 or $100 \mu \mathrm{g}$ cabergoline $\mathrm{kg}^{-1}$, although this difference was not significant (Fig. 1).

No significant variation in total litter weight was detected in vixens at week $4\left(F_{12,18}=0.88\right)$, week $5\left(F_{12,17}=0.95\right)$ or week $6\left(F_{12,17}=0.93\right)$ after whelping. Similarly, the variation in the mean cub weights for each vixen were not significant at week $4\left(F_{12,18}=0.31\right)$, week $5\left(F_{12,17}=0.21\right)$ and week $6\left(F_{12,17}=0.20\right)$ after whelping. There was no significant variation in the straight line growth rates, calculated as mean growth rates (g per week), for weeks 4, $5,6,7$ and 8 for each group $\left(F_{12,17}=0.19\right)$.

\section{Discussion}

In mammals, the maintenance of pregnancy is dependent on the secretion of luteotrophic hormones from the pituitary and biosynthesis of progesterone by the corpus luteum (Onclin and Verstegen, 1997). In ruminants, pigs (Sus scrofa) and horses (Equus caballus), LH is the primary luteotrophin; however, in rats (Rattus norvegicus) (Onclin and Verstegen, 1997) and ferrets (Mustela putorius) (Donovan, 1967; Murphy, 1979), both LH and prolactin are

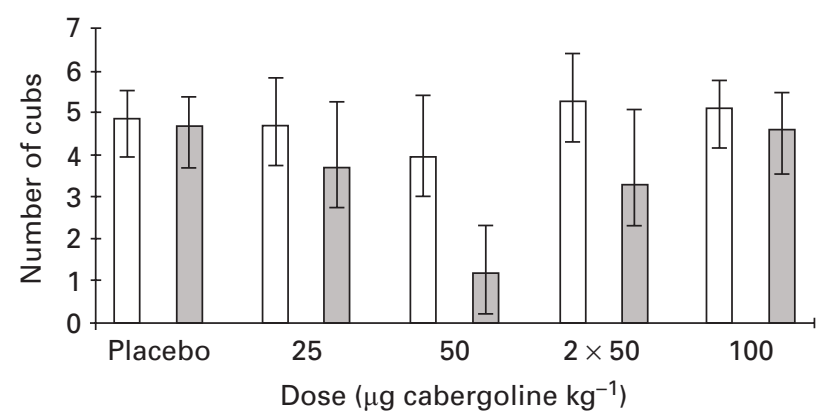

Fig. 1. Mean number of red fox (Vulpes vulpes) cubs born ( $\square$ ) and mean number of surviving cubs at weaning $(\square)$ for combined dose days when vixens received either a dose of the placebo $(n=9)$, or cabergoline at $25 \mu \mathrm{g} \mathrm{kg}^{-1}(n=7), 50 \mu \mathrm{g} \mathrm{kg}^{-1}(n=9), 2 \times 50 \mu \mathrm{g} \mathrm{kg}^{-1}$ $(n=7)$ or $100 \mu \mathrm{g} \mathrm{kg}^{-1}(n=7)(P<0.05)$.

required (Okkens et al., 1990). The endocrinology of pregnancy in the red fox is thought to be similar to that of domestic dogs, although foxes are seasonally mono-oestrus and have a gestation period of 52-53 days (Ryan, 1976; Lloyd, 1981; Coman, 1983), compared with an average gestation period of 64 days in domestic dogs (Concannon et al., 1989). In the red fox, concentrations of progesterone peak at the time of implantation and decrease during gestation (Bonnin et al., 1978; Hartley et al., 1994). A similar profile is observed in the blue fox (Alopex lagopus) (Mondain-Monval et al., 1985) and in dogs (Concannon et al., 1989). In hypophysectomized ferrets and dogs, LH was not essential for the maintenance of the corpus luteum (Onclin and Vestegen, 1997). Okkens et al. (1985) demonstrated that suppression of LH in dogs did not reduce progesterone synthesis during the second half of pregnancy and concluded that $\mathrm{LH}$ was not essential for the morphological or functional integrity of the corpus luteum at this stage. Concomitant administration of prolactin and cabergoline arrested the decrease in progesterone observed in dogs treated with cabergoline alone during the second half of pregnancy (Onclin and Verstegen, 1997). A similar administration of $\mathrm{LH}$ with cabergoline failed to reverse the decrease in progesterone compared with that of dogs that received cabergoline alone. In rats, a decrease in prolactin initiated by bromocriptine resulted in the loss of $\mathrm{LH}$ receptors, indicating that $\mathrm{LH}$ receptors may be dependent on prolactin (Grinwich et al., 1976; Murphy and Rajkumar, 1985; Onclin and Verstegen, 1997). Administration of exogenous $\mathrm{LH}$ in pregnant and non-pregnant dogs produced only a small and temporary increase in progesterone, and additional doses had a reduced effect (Onclin and Vestegen, 1997). Thus, these studies indicate that, in dogs, prolactin is likely to be the dominant luteotrophin during the second half of pregnancy. Cabergoline administration resulted in more rapid decreases in prolactin at day 30 than at day 25 of pregnancy (Onclin and Vestegen, 1997), although administration of cabergoline caused abortions in dogs as early as day 25 (Onclin et al., 1993). Progesterone production in dogs was markedly 
reduced by cabergoline administration on day 35 and day 42 of pregnancy, compared with a smaller reduction on day 28 (Hoffmann et al., 1996). However, the gradual regression of the corpus luteum in the second half of pregnancy, with a concomitant decrease in progesterone, occurs despite increasing availability of prolactin and the maintenance of prolactin receptor concentrations (Fernandes et al., 1987; Hoffmann et al., 1996). Dogs hypophysectomized on day 4 of pregnancy retained normal concentrations of progesterone compared with decreases observed in dogs hypophysectomized on day 18 (Okkens et al., 1986; Olson et al., 1989) indicating that, in early pregnancy, the canine corpus luteum may function independently of leutotrophic support (Okkens et al., 1986, 1990; Fernandes et al., 1987; Post et al., 1988; Vickery et al., 1988; Hoffmann et al., 1996).

Given the results of the above studies with dogs, in the present study, it was expected that oral administration of cabergoline was more likely to induce abortions in foxes at day 42 than at day 28 of pregnancy. In contrast, cabergoline doses of $100 \mu \mathrm{g} \mathrm{kg}^{-1}$ or $2 \times 50 \mu \mathrm{g} \mathrm{kg}{ }^{-1}$ resulted in abortions at day 28, but were less effective at days 35 and 42 . Although one vixen whelped successfully after receiving $100 \mu \mathrm{g}$ cabergoline $\mathrm{kg}^{-1}$, this was probably due to loss of cabergoline due to emesis, which was observed after treatment. Emesis is a commonly observed side-effect of all ergolines used orally at high doses, although the incidence is much less with cabergoline (Jöchle et al., 1987, 1989; Verstegen, 1993) and emesis was not observed in the preliminary dosage trial in which two doses of cabergoline of $100 \mu \mathrm{g} \mathrm{kg}^{-1}$ were used. Nevertheless, Juekenne and Vestegen (1997) observed that a small proportion of dogs receiving high doses of cabergoline were prone to emesis.

Doses of $100 \mu \mathrm{g}$ cabergoline $\mathrm{kg}^{-1}$ each day for 5 days resulted in abortions when administered between day 42 and day 47, indicating that prolactin is an essential luteotrophin in late pregnancy, but that long-term suppression is required to induce an abortion, hence the luteolytic effects of cabergoline appear dependent on increased duration of administration during the second half of pregnancy in foxes. Luteotrophic factors, possibly of fetoplacental origin, may be important in maintenance of the corpus luteum in late pregnancy in foxes. Placental luteotrophic hormones are in higher concentrations in rats with multiple conceptuses rather than a single conceptus (Ochiai et al., 1988; Sugino et al., 1991). Sugino et al. (1994) demonstrated that fetal re-absorption due to restraint stress, which resulted in decreased serum progesterone concentrations, was more frequent in rats with fewer conceptuses and that feto-placental units may influence the maintenance of the corpus luteum. Smith and McDonald (1974) suggested that luteotrophic factors originating from the placenta may play an important role in the maintenance of the corpus luteum in dogs, although such activity has not been detected (Talamantes, 1975) and the presence of feto-placental luteotrophic factors has not been investigated in foxes.
Table 3. Cub mortality before weaning in red fox (Vulpes vulpes) vixens that whelped successfully $(n)$ in each treatment group

\begin{tabular}{lclcc}
\hline & & \multicolumn{2}{c}{$\begin{array}{c}\text { Cub mortality in animals } \\
\text { treated on each day of } \\
\text { pregnancy }\end{array}$} \\
\cline { 3 - 5 } Group & $\begin{array}{c}\text { Dose of } \\
\text { cabergoline } \\
\left(\mu \mathrm{kg}^{-1}\right)\end{array}$ & $\begin{array}{c}\text { Day } 28 \\
n(\%)\end{array}$ & $\begin{array}{c}\text { Day } 35 \\
n(\%)\end{array}$ & $\begin{array}{c}\text { Day } 42 \\
n(\%)\end{array}$ \\
\hline 1 & 25 & $2(12)$ & $3(42)$ & $2(0)$ \\
& 50 & $3(93)$ & $3(79)$ & $3(56)$ \\
2 & 100 & $1(0)$ & $3(12)$ & $3(13)$ \\
3 & $50 \times 2$ & $1(100)$ & $4(28)$ & $2(29)$ \\
Total & Placebo $\times 2$ & $3(6)$ & $3(7)$ & $3(8)$ \\
\hline & & 10 & 16 & 13 \\
\hline
\end{tabular}

Lactation was not terminated in any vixen treated with cabergoline at day 28, 35 or 42; however, it was terminated in four of five vixens that received $100 \mu \mathrm{g}$ cabergoline $\mathrm{kg}^{-1}$ each day for 5 days from day 42 of pregnancy. The successful whelping and lactation in this vixen may have been due to a loss of the cabergoline by emesis, although this was not observed during the trial. All five vixens given the placebo whelped normally and lactation was observed in each animal. A pre-partum surge of prolactin is essential for the initiation of lactation (Kann and Denamur, 1974; Karg and Schams, 1974; Hearne et al., 1998) and for full development of the mammary glands during pregnancy (Hadley, 1988; Cowie, 1988; Rillema, 1994; Hooghe-Peters and Hooghe, 1995) in a number of eutherian species. Prolactin-inhibiting drugs, such as bromocriptine, have been demonstrated to inhibit or terminate lactation in domestic dogs (Mayer and Schutze, 1973) and cabergoline administration terminates lactation in cats (Felis domesticus) and rats (Jöchle et al., 1989; Ferraro et al., 1995). An oral dose of $5 \mu \mathrm{g}$ per $\mathrm{kg}$ per day of cabergoline resulted in cessation of lactation in beagles at 6 days after whelping, and doses between 2.5 and $5.0 \mu \mathrm{g}$ per kg per day resulted in mammary gland regression. Hearne et al. (1998) observed post-natal mortality in tammar wallabies (Macropus eugenii) after i.m. doses of cabergoline and bromocriptine, and suggested that this mortality was caused by a suppression of the pre-partum pulse of prolactin. It is unlikely that single or double doses of cabergoline administered at days 28, 35 and 42 inhibited the pre-partum pulse of prolactin, as the half-life of cabergoline is unlikely to suppress prolactin for more than a few days. Cabergoline remains bound to the $\mathrm{D}_{2}$ pituitary receptors in rats for more than $72 \mathrm{~h}$ (Di Salle et al., 1983; Onclin and Verstegen, 1997) and the suppression of prolactin persists for between 4 and 5 days from a single dose in dogs. In humans, a single oral dose of cabergoline causes inhibition of serum prolactin within hours of administration, which lasts for 7 days (Rolland et al., 1991; 
Ferraro et al., 1995). In the red fox, a single oral dose of $20 \mu \mathrm{g}$ cabergoline $\mathrm{kg}^{-1}$ resulted in a sustained suppression of prolactin for at least 3 days (Cowley, 1993). The observed post-natal mortality, which included the partial and full loss of litters over a 2 week period, is similar to results obtained by Ferraro et al. (1995) in which oral doses of 100-150 $\mu \mathrm{g}$ cabergoline $\mathrm{kg}^{-1}$ administered once or twice a week resulted in either the prevention of pregnancy, still birth or full or partial post-natal loss of rat pups in the first $12 \mathrm{~h}$ after parturition. The failure of mammary development in hypophysectomized rats injected with exogenous progesterone and oestrogen indicates that pituitary hormones are essential for mammary development during pregnancy in this species, although placental lactogens with prolactinlike activity may contribute to mammary development in rats (Daniel and Silberstein, 1987).

An alternative hypothesis to account for the partial loss of cubs during the present study is that cabergoline may have affected the maternal care of cubs by vixens. In the silver fox, disorders of maternal care have been related to changes in the concentrations of sex steroid hormones and prolactin during pregnancy (Oskina, 1991), and litter losses due to inadequate maternal behaviour and infanticide by primiparous silver foxes have also been well documented (Braastad and Bakken, 1993). In the present study, the effect of cabergoline on maternal behaviour and the contribution of poor maternal care to cub mortality could not be confirmed.

The results of this study support the conclusions of a previous study in which cabergoline delivered in bait was found to affect the reproductive success of red foxes in the field (Marks and Short, 1996; Marks et al., 1996). It is likely that the reduction in the number of cubs born at natal dens treated with cabergoline baits was due to a combined effect of abortion and post-natal mortality. Termination of lactation and cub mortality may also be possible if baits containing cabergoline were ingested for several consecutive days in the final week of pregnancy. Food caching is a well recognized behaviour in red foxes (Macdonald, 1977; Jeselnik and Brisbin, 1980), and Saunders et al. (1999) confirmed that caching and later ingestion of Foxoff ${ }^{\circledR}$ baits is common. This behaviour would increase the likelihood that bait ingestion could occur over an extended period and potentially terminate lactation. It is unknown how early in pregnancy that single doses of $100 \mu \mathrm{g}$ cabergoline $\mathrm{kg}^{-1}$ may cause abortions in silver foxes, or how early such doses will affect mammary development in vixens. Hartley et al. (1994) suggested that luteotrophic support by prolactin was essential from day 21 of pregnancy in the red fox. Prolactin concentrations started to increase after the second week of pregnancy in the blue fox (Møller et al., 1984a,b). The ability of a single oral dose of cabergoline to cause abortions in foxes should be investigated at least as early as day 14 of pregnancy. Cabergoline reliably prevents the implantation of blastocysts and development of embryos in rats when administered on days 1-3 of pregnancy due to the suppression of progesterone (Negishi et al., 1997). Consequently, the prevention of embryo implantation is another possible means by which cabergoline could affect the reproductive success of vixens and this area is also worthy of further investigation.

This study was jointly funded by Environment Australia, the Phillip Island Nature Park, the Vertebrate Biocontrol Cooperative Research Centre (VB-CRC) and the Department of Natural Resources and Environment (Victoria). The authors wish to thank R. Holopainen, A. Helin, M. Tengvall and S. Keski-Nisula from the Juankoski Fur Farm (Department of Applied Zoology and Veterinary Medicine, University of Kuopio) for their expert technical support during this trial. Many thanks to O. Kaasinen for his willingness to assist with the supply of foxes for the second trial. Staff of the VB-CRC provided useful input during the early design of this trial and the authors extend their thanks to B. Seamark, P. Bird and L. Hinds. J. Reynolds provided statistical support during the analysis of data in this study. The manuscript benefited from constructive criticisms made by M. Renfree, K. Nicholas and two anonymous referees.

\section{References}

Allen SH (1983) Comparison of red fox litter sizes determined from counts of embryos and placental scars Journal of Wildlife Management 47 860-863

Anon (1996) Threat Abatement Plan for Predation of Wildlife by the European Red Fox Australian Nature Conservation Agency, Canberra

Belcher CA (1998) Susceptibility of the tiger quoll, Dasyurus maculatus, and the eastern quoll, D. viverrinus, to 1080-poisoned baits in control programs for vertebrate pests in eastern Australia Wildlife Research $2533-40$

Benedetti MS, Dorset P, Barone D, Efthymiopoulos G and Roncucci R (1990) In vitro interactions of cabergoline with rat brain dopamine receptors labelled with propylnorapomorphine European Journal of Pharmacology 16 399-409

Bomford M (1990) A Role for Fertility Control in Wildlife Management? Australian Government Publishing Service, Canberra

Bomford M and $\mathbf{O}^{\prime}$ Brien $\mathbf{P}$ (1992) A role for fertility control in wildlife management in Australia. In Proceedings of the Vertebrate Pest Control Conference pp 344-347 University of California, Davis

Bonnin M, Mondain-Monval M and Dutourne B (1978) Oestrogen and progesterone concentrations in peripheral blood in pregnant red foxes (Vulpes vulpes) Journal of Reproduction and Fertility 54 37-41

Braastad B and Bakken M (1993) Maternal infanticide and periparturient behaviour in farmed silver foxes (Vulpes vulpes) Applied Animal Behavioural Science 36 347-361

Caballero-Gordo A, Lopez-Nazareno N, Caldaray M, Caballero JL, Mancheno E and Sghedoni D (1991) Oral cabergoline: single-dose inhibition of puerperal lactation Journal of Reproductive Medicine $\mathbf{3 6}$ $717-721$

Coman BJ (1983) Red fox. In The Complete Book of Australian Mammals pp 486-487 Ed. R Strahan. Angus and Robertson, Sydney

Concannon PW, McCann JP and Temple M (1989) Biology and endocrinology of ovulation, pregnancy and parturition in the dog Journal of Reproduction and Fertility Supplement 39 3-25

Conley AJ and Evans LE (1984) Bromocryptine induced abortion in the bitch. In Proceedings of the 10th International Congress of Animal Reproduction and Artificial Insemination p. 504 University of Illinois, Champaign, Urbana

Cowie AT (1988) Lactation. In Hormonal Control of Reproduction pp 195-231 Eds CR Austin and RV Short. Cambridge University Press, Cambridge

Cowley M (1993) Reproductive Control of Foxes BSc Honours Thesis, Department of Physiology, Monash University, Clayton

Dall'Ara A, Lima L, Cocchi E, Di Salle E, Cancio E, Devensa J and Muller EE (1988) Inhibitory effect of cabergoline on the development of estrogeninduced prolactin-secreting adenomas of the pituitary European Journal of Pharmacology 151 97-102 
Daniel CW and Silberstein GB (1987) Postnatal development of the rodent mammary gland. In The Mammary Gland pp 1-36 Eds MC Neville and CW Daniel. Plenum, New York

Di Salle E, Ornati G, Guidici D and Briatico G (1983) Prolactin lowering effect of a new ergoline derivative, PCE 21336, in the rat: a comparison with bromocryptine Acta Endocrinology Supplement 103 265-273

Donovan BT (1967) The control of corpus luteum function in the ferret Archives d'Anatomie et de Morphologie Experimentale 56 315-325

Fernandes P, Bowen R, Kostas AC, Sawyer H and Nett TM (1987) Luteal function in the bitch: changes during dioestrus in pituitary concentration of $\mathrm{LH}$ and the number of luteal receptors for lutenizing hormone and prolactin Biology of Reproduction 37 804-811

Ferraro F, Nisoli LGC, Maffeo G and Ballabio R (1992) Effetto della somministrazione di un inibitore prolattinico nei piccioni Documenti Veterinaria e Biochimica 11 49-52

Ferraro F, Nisoli LGS, Salvo R, Maffeo G and Jöchle W (1995) Periodic use of cabergoline, a prolactin inhibitor, for control of reproductive success in rats - work in progress Theriogenology 44 1-7

Fougner JA (1989) Artificial insemination in fox breeding Journal of Reproduction and Fertility Supplement 39 317-323

Fougner JA, Aamdal J and Andersen K (1973) Intra-uterine insemination with frozen semen in the blue fox Nordisk Veterinär Medicin 25 144-149

Grinwich DL, Hichens M and Behrman HR (1976) Control of the LH receptor by prolactin and prostoglandin $\mathrm{F}_{2}$-alpha in rat corpora lutea Biology of Reproduction 14 212-218

Hadley ME (1988) Endocrinology Prentice-Hall, Sydney

Hartley FGL, Follet BK, Harris S, Hirst D and McNeilly AS (1994) The endocrinology of reproductive failure in foxes (Vulpes vulpes) Journal of Reproduction and Fertility $100341-346$

Hearne CM, Shaw G, Short RV and Renfree MB (1998) The effects of cabergoline on reproduction in three families of Australian marsupials Journal of Reproduction and Fertility 113 151-157

Hoffmann B, Riesenbeck A and Klein R (1996) Reproductive endocrinology of bitches Animal Reproduction Science 42 275-288

Hooghe-Peters EL and Hooghe RH (1995) The mammary gland: milk proteins from leukocytes. In Growth Hormone Prolactin and IGF-I as Lymphohemopoietic Cytokines pp 147-154 Eds EL Hooghe-Peters and RH Hooghe. Springer-Verlag, New York

Jalkanen L (1992) The female silver fox compared to the blue fox. In Reproduction in Carnivorous Fur Bearing Animals pp 135-138 Eds A Tauson and $\mathrm{M}$ Valtonen. Jordbrugsforlaget, Copenhagen

Jeselnik DL and Brisbin IL (1980) Food-caching behaviour of captive-reared foxes Applied Animal Ethology 6 363-367

Jeukenne P and Verstegen J (1997) Termination of dioestrus and induction of oestrus in diooestrus nonpregnant bitches by the prolactin antagonist cabergoline Journal of Reproduction and Fertility Supplement 51 59-66

Jöchle W, Ballabio R and di Salle E (1987) Inhibition of lactation in the beagle bitch to the prolactin inhibitor cabergoline: dose response and long-term safety Theriogenology 27 799-811

Jöchle W, Arbeiter K, Post K, Ballabio R and D'Ver AS (1989) Effects on pseudopregnancy, pregnancy and interoestrus intervals of pharmacological suppression of prolactin secretion in female dogs and cats Journal of Reproduction and Fertility Supplement 39 199-207

Kann G and Denamur R (1974) Possible role of prolactin during the ooestrus cycle and gestation in the ewe Journal of Reproduction and Fertility 39 473-483

Karg H and Schams D (1974) Prolactin release in cattle Journal of Reproduction and Fertility $39463-472$

King DR (1989) An assessment of the hazard posed to northern quolls (Dasyurus hallucatus) by aerial baiting with 1080 to control dingos Australian Wildlife Research 16 569-574

Lindström E (1986) Territory inheritance and the evolution of group-living in carnivores Animal Behaviour 34 1825-1835

Lloyd HG (1981) The Red Fox Batesford Press, London

Macdonald DW (1977) On the food preference in the red fox Mammal Review 7 7-23

Mcllroy JC (1993) Susceptibility of target and non-target animals to 1080. In Proceedings of the Science Workshop on 1080 pp 90-96 Eds AA Seawright and CT Eason. The Royal Society of New Zealand
Mansergh I and Marks CA (1993) Predation of native wildlife by the introduced red fox (Vulpes vulpes) Flora and Fauna Guarantee Action Statement No 44 Department of Conservation and Natural Resources, Victoria

Marks CA and Short RV (1996) Out-foxing the fox Nature Australia 25 39-45

Marks CA, Nijk M, Gigliotti F, Busana F and Short RV (1996) Preliminary field assessment of a cabergoline baiting campaign for the reproductive control of the red fox (Vulpes vulpes) Wildlife Research 23 161-168

Mayer P and Schutze E (1973) Effect of 2-Br- $\alpha$-ergokryptine (CB 154) on lactation in the bitch Experimentia 29 484-485

Møller OM, Mondain-Monval M, Smith A, Metzger E and Scholler R (1984a) Temporal relationships between hormonal concentrations and electrical resistance of the vaginal tract of blue foxes (Alopex lagopus) at pro-oestrus and oestrus Journal of Reproduction and Fertility 70 15-24

Møller OM, Mondain-Monval M, Smith A and Scholler R (1984b) Hormonal concentrations of blue foxes during pregnancy and parturition. In Proceedings of the 3rd International Scientific Congress on Fur Animal Production 7 pp Versailles, France

Mondain-Monval M, Møller OM, Smith AJ, McNeilly AS and Scholler R (1985) Seasonal variations of plasma prolactin and LH concentrations in the female blue fox (Alopex lagopus) Journal of Reproduction and Fertility 74 439-448

Mononen J, Harri M, Rekilä T, Korhonen H and Niemela P (1995) Use of nest boxes by young farmed silver foxes (Vulpes vulpes) in autumn Applied Animal Behaviour Science 43 213-221

Mononen J, Harri M and Rekilä T (1996) Comparison of preferences of farmed silver and blue foxes for cages with or without nest boxes ACTA Agriculturae Scandinavica 46 117-124

Murphy BD (1979) The role of prolactin in implantation and maintenance in the ferret Biology of Reproduction 21 517-521

Murphy BD and Rajkumar K (1985) Prolactin as a luteotrophin Canadian Journal of Physiology and Pharmacology 63 257-264

Negishi H, Kumar GP, Laloraya M and Koide SS (1997) Neutralisation of pregnancy-preventing activity of cabergoline, a dopamine agonist, with progesterone Theriogenology 48 241-246

Ochiai K, Kato H, Kelly DA and Rothchild I (1988) The importance of the luteolytic effect of the pituitary in understanding the placental control of the rat corpus luteum Endocrinology 112 1687-1695

Okkens AC, Dieleman SJ, Bevers MM and Willemse AH (1985) Evidence of the non-involvement of the uterus in the lifespan of the corpus luteum in the cyclic dog Veterinary Quarterly 7 169-173

Okkens AC, Dieleman SJ, Bevers MM and Willemse AH (1986) Influence of hypophysectomy on the lifespan of the corpus luteum in the cycling dog Journal of Reproduction and Fertility 77 187-192

Okkens AC, Bevers MM, Dieleman SJ and Willemse AH (1990) Evidence for prolactin as the main luteotropic factor in the cyclic dog Veterinary Quarterly 12 193-201

Olson PN, Nett TM, Bowen RA, Sawer HR and Niswender GD (1989) Endocrine regulation of the corpus luteum of the bitch as a potential target for altering fertility Journal of Reproduction and Fertility Supplement 39 27-40

Onclin K and Verstegen JP (1997) In vivo investigation of luteal function in dogs: effects of cabergoline, a dopamine agonist, and prolactin on progesterone secretion during mid-pregnancy and dioestrus Domestic Animal Endocrinology 14 25-38

Onclin K, Silva LDM, Donnay I and Vestegen JP (1993) Luteotrophic action of prolactin in dogs and the effects of a dopamine agonist, cabergoline Journal of Reproduction and Fertility Supplement 47 403-409

Oskina IN (1991) Hormonal aspects of maternal behaviour in the silver fox Scientifur 15 313-314

Pontiroli AE, Viberti GC, Mangili R, Cammelli L and Dubini A (1987) Selective and extremely long inhibition of prolactin release in man by 1 ethyl-3-(3'-dimethylaminopropyl)-3-(6'-allylergoline-8- $\beta$-carbonyl)urea-diphosphate (FCE 21336) British Journal of Clinical Pharmacology 23 433-438

Post K, Evans LE and Jochle W (1988) Effects of prolactin suppression by cabergoline on the pregnancy of the bitch Theriogenology 29 1233-1243 
Rillema JA (1994) Development of the mammary gland and lactation Trends in Endocrinology and Metabolism 5 149-154

Rolland R, Piscitelli G, Ferrari C and Petroccione A (1991) Single dose cabergoline versus bromocriptine in inhibition of puerperal lactation: randomised double-blind, multicentre study British Medical Journal 302 1367-1371

Ryan GE (1976) Observations on the reproduction and age structure of the fox (Vulpes vulpes) in New South Wales Australian Wildlife Research 311-20

Saunders G, Coman BJ, Kinnear J and Braysher M (1995) Managing Vertebrate Pests: Foxes Australian Government Publishing Service, Canberra

Saunders G, Kay BJ and McLeod J (1999) Caching of baits by foxes (Vulpes vulpes) on agricultural lands Wildlife Research 26 335-340

Smeds K (1991) Rävens Fruktsamhetsegenskapers Arvbarhet University of Helsinki, Helsinki

Smith MS and McDonald LF (1974) Serum levels of luteinizing hormone and progesterone during the oestrous cycle, pseudo-pregnancy and pregnancy, and parturition in the dog Endocrinology 94 405-411

Soderquist TR and Serena M (1993) Predicted susceptibility of Dasyurus geoffroii to canid baiting programmes: variation due to sex, season and bait type Wildlife Research 20 287-296

Sugino N, Tamura H, Nakamura Y, Ueda K and Kato H (1991) Differential mechanisms for the inhibition of progesterone secretion by ACTH and corticosterone in pregnant rats Journal of Endocrinology $\mathbf{1 2 9}$ 405-410

Sugino N, Nakamura Y, Okuno N, Shimamura K, Teyama T, Ishimatsu M and Kato H (1994) Effects of restraint stress on luteal function in rats during mid-pregnancy Journal of Reproduction and Fertility 101 23-26

Talamantes F (1975) Comparative study of the occurrence of placental prolactin among mammals General and Comparative Endocrinology 27 115-121

Vickery BH, Bergstrom K, Miller K and Goodpasture JC (1988) Synergistic suppressive effects of an LHRH antagonist and prostaglandin analog on early luteal function and pregnancy in dogs Biology of Reproduction Supplement $\mathbf{3 8} 56$

Voigt DR (1987) Red fox. In Wild Furbearer Management and Conservation in North America pp 379-392 Eds M Novak, J Baker, ME Obbard and B Malloch. Ontario Ministry of Natural Resources, Ontario

Zar HJ (1984) Biostatistical Analysis Prentice-Hall, Sydney

Received 21 March 2000

First decision 26 June 2000

Revised manuscript received 16 February 2001

Accepted 16 February 2001 